\title{
Nadverelementerne og billedsynet
}

\author{
Af Leif Kallesen
}

I foråret 1806 blev Grundtvig dybt påvirket af romantikken og dens livstolkning. Især Schelling gjorde indtryk på ham. Ifølge den romantiske idealisme, som Schelling repræsenterede, kan den endelige, sanselige, ydre og synlige tilværelse ikke anses for den højeste virkelighed. Verden, som den ligger åben for menneskets sanser, er kun et skin, bag hvilket den evige, uforanderlige virkelighed skjuler sig for øjet. Men, siger romantikken, digteren og geniet formår i det synlige og timelige at erkende den ideale natur, virkeligheden. Endeligheden, sanseligheden og timeligheden er fremtrædelsesformen for og billedet af det evige og usynlige. Betydning har den ydre verden kun, for så vidt den er middel til erkendelse af det ideale og evige. Sondringen mellem det jordiske, det timelige, det synlige og det legemlige på den ene side og det himmelske, det evige, det usynlige og det åndelige på den anden satte sit præg på Grundtvigs tilværelsesforståelse. Og den tanke, at det jordiske og synlige er et spejlbillede af det himmelske og usynlige blev i afgørende grad bestemmende for Grundtvigs syn på den verden, mennesket kan erkende gennem sanserne. Grundtvig modificerede ganske vist tanken, idet han hævdede, at det var ethvert menneskes mulighed at se et billede af det evige og himmelske $i$ alt det synlige og jordiske. Ikke kun for geniet åbenbarer det evige sig i det endelige.

Når der i det følgende tales om 'billedsynet', dækker begrebet altså over den tanke, at det jordiske er et spejlbillede af det himmelske. Og sigtet med nærværende artikel er da at vise, hvilken afgørende og vedblivende betydning dette billedsyn fik for Grundtvigs syn på nadverelementerne. Fremstillingen søger at svare på tre spørgsmål: 1) hvornår gennemføres for første gang billedsynet på nadverelementerne? 2) hvorledes kommer det til udtryk i billed- 
sproget? 3) hvilken betydning vedbliver billedsynet at have, efter at Grundtvig under indtryk af Irenæus har opvurderet sit syn på den skabte verden og tilkendt legemligheden realitet?

\section{Grundtvigs negative forhold til nadverelementerne}

På Grundtvigs tid blev uddelingen af alterbrødet og altervinen ledsaget af ordene: „Dette er Jesu sande Legeme/Blod «. Disse ord, der rent grammatisk er meget påpegende (»dette«), og som i sig rummer en anticalvinsk polemik (»sande«), kan kun forstås således, at det stykke brød, som altergæsten spiser, er identisk med Jesu legeme, og at den smule vin, som altergæsten drikker, er identisk med Jesu blod.

Grundtvig forligte sig aldrig med disse uddelingsord, netop fordi de så bastant forbandt brødet med Jesu legeme og vinen med Jesu blod. Livet igennem nærede Grundtvig en udtalt modvilje mod at identificere elementerne med Jesu legeme og blod. Tydeligst kommer Grundtvigs negative nadversyn til udtryk i den tidlige afhandling Om Religion og Liturgie (1806). Afsnittet om nadveren bærer tydeligt præg af at være et opgør med »Transubstantiationens bespottelige Lære« (dette og de følgende citater fra afhandlingen findes i VU, I, s. $135 \mathrm{og}$ /eller s. 136). Og med disse ord tænker Grundtvig ikke blot på den katolske nadverteologi. Grundtvig mener nemlig, at den samtidige lutherske teologi stærkt nærmer sig forvandlingslæren, når den erklærer brødet og vinen for Jesu legeme og blod. Det forargelige ved denne lære er, at det evige fængsles i »det Endeliges Produktioner". Det allerhelligste, som man kun ved troen kan få del i, kan ikke nydes gennem munden, hedder det indirekte. Det gælder om ikke at fæste det himmelske til det jordiske, men derimod at forene os med det himmelske »hævede ved dets gudelige Kraft«. Schellingrusen fra foråret 1806 med dens tale om at have sig op til det højeste er afdæmpet. Nu haves mennesket ved det himmelskes kraft; men mødet sker stadig så at sige over det endeliges plan. Vi får her et tydeligt indtryk af Grundtvigs tilværelsesforståelse: det himmelske og evige er adskilt fra det jordiske og timelige, der kun er et skin af virkeligheden. Man sporer i disse 
udtalelser et negativt forhold til det legemlige og håndgribelige og derfor også til elementerne, brødet og vinen.

Som argumenter imod en bastant lære om Jesu legems og blods udvortes nærvær i, med og under brødet og vinen anfører Grundtvig blandt andet et nytestamentligt skriftsted og en oldkirkelig nadverlære.

I Det Nye Testamente finder Grundtvig støtte i den paulinske sprogbrug 1.Kor.10,16. På Grundtvigs tid lød den danske oversættelse således: "Velsignelsens Kalk, som vi velsigne, er den ikke Christi Blods Samfund? det Brød, som vi bryde, er det ikke Christi Legems Samfund?« Nøgleordet er samfund eller fællesskab. Paulus formår her at tale om nadverens virkelige evne til at forene altergæsten med Kristus uden dog at identificere elementerne med Jesu legeme og blod. Således har Grundtvig (i øvrigt i overensstemmelse med moderne nytestamentlig eksegese) forstået verset, og derfor kan han bruge det som et korrektiv til den i hans øjne substantielle sammenknytning af elementerne og Jesu legeme og blod, som den lutherske tradition gør sig skyldig i, når brødet og vinen erklæres for Jesu legeme og blod. Grundtvig siger om 1.Kor.10,16: „Vilde Paulus have talt saaledes, dersom han havde troet, som de, der forfattede vor Confession, at Christi Legeme i, med og under Brødet annammes i Munden, og - vi gyse ved Tanken - knuses imellem Tænderne?« Ved at knytte til ved 1.Kor.10,16 får Grundtvig mulighed for at tale om »den sande Troendes Forening... med sin Gud og Frelser « i nadveren uden at havne i læren om Kristi legemlige nærvær »imellem Tænderne«. Grundtvigs fremhævelse af 1.Kor.10,16 allerede i 1806 er interessant af den grund, at dette skriftsted vedblev at spille en afgørende rolle i Grundtvigs nadverteologi hele livet igennem. Gang på gang sammenfatter han sit eget syn med disse Paulusord. Af de nytestamentlige skriftsteder, som omhandler nadveren, er 1.Kor.10,16 vel nok det hyppigst citerede i Grundtvigs prædikener.

Som nævnt henter Grundtvig også hjælp hos en oldkirkelig nadverteologi $\mathrm{i}$ bestræbelserne på at imødegå sin samtids lutherske nadverlære. Det drejer sig om Klemens og Origenes, om hvem det hedder, at de forkastede "Læren om den saakaldte praesentia realis«, det vil sige den "virkelige (udvortes) Nærværelse«. Grundtvig har med rette ment, at disse oldkirkelige teologer kunne bruges som argument imod den lutherske ortodoksis lære om, at Kristi legeme 
og blod i, med og under brødet og vinen spises og drikkes med munden. Ifølge Origenes er kropsligheden og alt materielt uforeneligt med Gudsbegrebet. Origenes betragter elementerne som symboler på den sande sjælespise, som er Kristi ord. Brødet og vinen på alterbordet har præcis den samme virkning som alle andre fødemidler. Når Kristus, Guds Ord, taler om sit legeme og blod, så mener han ikke de synlige elementer, brød og vin, men sakramentordet, som forordnede brødets brydelse og kalkens uddeling; for intet andet end ordet, som nærer og opliver hjertet, kan være Kristi legeme og blod (Origenes: Matth. comm. ser. 85). Samme tolkning af Origenes findes hos $R$. Seeberg, der i sin Lehrbuch der Dogmengeschichte skriver, at nadverens virkning ifølge Origenes udelukkende er bundet til ordet, der udtales ved nadverfejringen. Elementernes betydning er kun symbolsk (bd. I, s.439f.).

Grundtvigs brug af Origenes er helt legitim i den frontstilling, som han ser sig selv stående $i$, fordi Origenes tolker netop elementerne, men ikke nadveren som sådan symbolsk. Gennem nadveren meddeles virkelig himmelske kræfter, som bringer nadvergæsten $\mathrm{i}$ samfund med Gud. Det er præcist dette standpunkt, Grundtvig indtager $\mathrm{i}$ afhandlingen; tænk blot på den positive tale om den troendes forening med Herren i nadveren, på anvendelsen af 1.Kor.10,16 og endelig på udfaldet mod en udvortes nærværelse.

Denne indledende gennemgang af et af Grundtvigs tidlige arbejder har givet et indtryk af hans negative forhold til elementerne. Brødet og vinen er ikke Kristi legeme og blod. I det hele taget formulerer Grundtvig sit nadversyn i negative vendinger i den pågældende afhandling. Det positive indhold af hans nadverteologi fremstilles ikke. Han siger kun, hvad elementerne ikke er. Derimod siger han intet om, hvorledes han betragter dem positivt udtrykt. Han vover ikke at sige som Origenes, at nadverelementerne er symboler på Kristus, Guds Ord.

Påberåbelsen af Origenes er interessant, dels fordi Grundtvig senere når frem til den opfattelse, at elementerne er billeder på sakramentets indhold, og dels fordi den senere Grundtvig understreger sit tankemæssige slægtskab med Irenæus. Irenæus på den ene side og Klemens og Origenes på den anden står imidlertid som repræsentanter for to forskellige teologiske hovedtyper. Hvad nadveropfattelsen angår, er forskellen i al korthed følgende: Irenæus hævder, at det brød, hvorover indstiftelsesordene har lydt, ikke 
mere er almindeligt brød, men et takoffer sammensat af en himmelsk og en jordisk bestanddel. I kraft af disse to bestanddele er brødet Kristi legeme og vinen Kristi blod. Således får nadverelementerne en legemlig virkning på nadvergæstens krop, når den optager brødet og vinen i sig (se f.eks. Holmquist og Nørregaard: Kirkehistorie, bd. I, 3. udg., s. 135). Origenes derimod mener, at nadverelementerne blot er synlige tegn og symboler. Nadverens kraft er ikke bundet til disse elementer. Ordet alene er nok. Vi drikker Kristi blod, siger Origenes, når vi modtager ("recipimus" og "suscipimus«) hans ord. I modsætning til Irenæus regner Origenes kun med en virkning på sjælen.

Det negative forhold til nadverelementerne, som vi har konstateret det $\mathrm{i}$ afhandlingen Om Religion og Liturgie fra 1806, er ikke blot et forbigående lune. Modviljen mod at identificere brødet og vinen med Jesu legeme og blod møder vi også efter 1810, hvor Grundtvig gennemgik en omvendelse til traditionel luthersk teologi. Grundtvigs første gendigtning af det 5. vers i Bertel Pedersøns salme »Mit Barn fryct den sande Gud « er et illustrerende eksempel på, hvorledes Grundtvig undgår sproglige udtryk, der kan tage sig ud som en identificering af brødet og vinen med Jesu legeme og blod. Forlæg og gendigtning (fra 1825?) anføres efter hinanden:

Spiiss min Sjæl, o Jesu sød, Med dit Kiød, det rene Brød, Vederqvæg mig, Frelser min, Med dit Blod, den sødest Vïn,

Til din Døds Hukommelse,

Oc min Synds Forladelse, Trefoldighed Priiss oc Ære skee.

(mine udhævelser)

Gak nu glad til Herrens Bord! Troe ham kiærlig paa Hans Ord Mæt din Sjæl, som han dig bød Med det sande Livets Brød Livets Brød det er han selv Og hans Blod er Livets Elv, Glemmer Hjertet ham, da skiælv! 
De appositionelle konstruktioner i forlæggets 2. og 4. linie kan tolkes som en opdeling af Kristi menneskelighed på de to elementer. Det er muligt i dette vers at se en tolkning af elementerne forstået på den måde, at brødet identificeres med Kristi kød og vinen med Kristi blod. Om dette har været forfatterens hensigt, er uden betydning. Grundtvig har i hvert fald med sin gendigtning søgt at undgå en sådan udlægning. Derfor har han valgt en konstruktion uden elementernes omtale i appositioner. Grundtvig gør i stedet brug af Johannesevangeliets billedlige Kristusbenævnelser. Således henter han f.eks. udtrykket "Livets Brød» fra Johs.6,48. Hele Kristus og ikke blot hans legeme er livets brød, sådan som det også er tilfældet hos Johs. Ligeledes er "Livets Elv« et billede på Kristus. Ved hjælp af den lånte sprogbrug får Grundtvig sagt, at den sande mad ved nadveren er Kristus selv. Gendigtningen åbner ingen direkte mulighed for at identificere elementerne med Kristi legeme og blod.

Som sagt fastholder Grundtvig sit negative syn på elementerne op gennem årene. Han kan ikke acceptere den tanke, at elementerne skulle være Kristi legeme og blod. Helt uden omsvøb udtaler han sig på skærtorsdag 1839: "...thi er det Herrens Ord, vi skal troe, og er det dem der bringe hvad de lyde, saa er det naturligviis ogsaa til dem, vi skal holde os og i dem vi skal søge og skiønne paa Herrens Legeme. Det giælder altsaa ikke om den Tro, at Brødet er Christi Legeme og Vinen Christi Blod» (s. 6). Senere i samme prædiken hedder det, at Kristus "vil gienføde Troen i os paa den dybe Hemmelighed, at Han er heel, baade med Sjæl og Legeme i sit Ord « (s. 7). I denne prædiken er det Grundtvigs anliggende at fastholde og understrege tanken om Herrens virkelige nærvær i nadveren uden at binde dette nærvær til elementerne. Realpræsensen kommer i stedet til at bero på de hørlige indstiftelsesord.

\section{Nadverelementerne som billeder}

Det negative syn på det legemlige inklusive nadverelementerne har sin grund i den fra romantikken arvede adskillelse mellem det synlige og timelige og det usynlige og evige. Gang på gang minder prædikanten sine tilhørere om denne modsætning, der omfatter 
hele tilværelsen. I løbet af sidste halvår af 1821 er spørgsmålet om forholdet mellem det synlige og det usynlige flere gange til behandling i prædikenerne. Det er især nadveren, der skærper problemstillingen. I en række prædikener fra dette efterår arbejder Grundtvig med at anlægge sin romantiske tilværelsesforståelse på alterets sakramente. 7.s.e. trinitatis, hvor teksten er bespisningsunderet, taler Grundtvig om at "hæve vor Sjæl fra de synlige Ting som ere timelige til de usynlige, som ere evige" (s. 13). Fredag den 26. okt. fremføres så en skriftbegrundelse for tilværelsestolkningen. Kol.3,1-2 tages til indtægt for den værdiladede sondring mellem det synlige og timelige og det usynlige og evige. Grundtvig skriver (på sin ejendommeligt forkortende måde): "vi ansee ikke de synl men de usynl thi de Slge ere timelige men de Usl evige - vi see i de Synlige de Usynlige og bruge dem viselig til Guds Ære» (s. 3). Under slutstregen efter prædikenen står der: "Det Usynlige med det Synlige i den Hellige Nadver det tragte vi efter i Jesu Navn Amen« (s. 4). Med bibelsk begrundelse i Kol.3,1-2 betragtes nadveren her under den romantiske tilværelsesforståelses synsvinkel; og billedsynet føjes uformidlet til, hvilket er mere end skriftstedet kan bære. Man sidder tilbage med en fornemmelse af, at de synlige nadverelementer og indstiftelsesordenes hårde »er " frembyder en hindring for billedsynets universelle gyldighed. Derfor forlegenhedsløsningen efter prædikenen: "Det Usynlige med det Synlige i den Hellige Nadver «. Grundtvig vover endnu ikke at sige, at elementerne som alt andet synligt er et billede af det usynlige. Det synlige ved nadveren må i modsætning til alle andre synlige ting have en eller anden værdi i sig selv, som gør det værd at tragte efter; hvilken betydning er uklart for Grundtvig. Måske er der tale om et uafklaret forhold til den lutherske nadverteologi overhovedet.

Fredag den 23. nov. (1821) vover Grundtvig imidlertid springet. I en prædiken til denne dag gennemfører han billedsynet også på nadverelementerne. På side 4 i manuskriptet står der: „Det Huus vi ere her forsamlede udi, det kalde vi og Herrens Huus, fordi Guds Ord udvortes lyder og oplyser der og Bordet hist det kalde vi Guds Alter det Brød som vi bryde, den Kalk vi velsigne kalde vi vor Herres Jesu Christi Legeme og Blod, og det er ret, thi det er sande Billeder af det heroven til, og er vi aandelig nærværende derved, da er vi og i Herrens Huus; men vi kan ogsaa være legemlig nærværen- 
de og fremmede for Aanden, holde os med Læben nær til Herren skiøndt Hjertet er langt borte, og da, vee os!«I 1806 var det bespotteligt at kalde brødet og vinen for Jesu legeme og blod, fordi det blev forstået som en tingsliggørelse af det åndelige. Nu kan Grundtvig forlige sig med denne tale, fordi den tolkes billedligt. Det synlige og udvortes, brødet og vinen, afbilder noget åndeligt og himmelsk, og det gælder da om at omgås det legemlige rigtigt, så det bliver et billede på det egentlige, nemlig det åndelige og himmelske; for en blot udvortes gudstjeneste og nadverdeltagelse bringer ikke mennesket i samfund med Gud.

Grundtvig kan nu udtrykke sit syn på elementerne i positive vendinger. Brødet og vinen er billeder på sakramentets åndelige indhold.

I de følgende år udfoldes billedsynet fuldt ud i prædikenerne; men det bliver efterhånden på Grundtvigs egne betingelser. Han udnytter i stigende grad den romantiske verdensforståelse i en kombination med en skabelsesteologisk betragtningsmåde og undgår derved en symbolsk elementtolkning, der i modsætning til en billedlig tolkning hviler på en ringeagt for det skabte og synlige.

På septuagesima søndag 1822 bliver vinen og kalken billede på Jesu ord og gerninger (s. 3); men endnu tydeligere slår billedsynet igennem på 2.s.e.trinitatis 1822 . Grundtvig proklamerer her, at alle de jordiske og timelige ting er lignelser og skygger af det himmelske og evige, og at det synlige nødvendigvis altid er et billede af det usynlige (s. 7). I denne prædiken er den romantiske tilværelsesforståelses syn på den sanselige verden som skyggebillede af det oversanselige helt gennemført. Nadverelementerne indtager ingen særstilling; også de betragtes nu under billedsynets vinkel. Dobbeltheden synligt - usynligt i nadveren bliver nærmest et bevis på gyldigheden af sondringen mellem det legemlige og det åndelige. Grundtvigs forhold til nadverelementerne er her klart. Med billedsynets gennemførelse i 1821-22 har han fået et positivt forhold til disse elementer. Skærtorsdagsprædikenen fra det følgende år (1823) viser, at den billedlige udtydning af det synlige ved nadveren er kommet for at blive. Nadveren er et tegn, siger Grundtvig, "forsaavidt der med synlige Ting skeer en legemlig Handling med en høiere, billedlig Betydning ... forsaavidt Brød og Viin i Nadveren betegner Frelseren, som hengav sit Legeme og udøste sit Blod for os« (s. 8). Sakramentets ydre bestanddele er »forordnede til øiensynlig at 
betegne« det åndelige indhold (sst.). Grundtvig indrømmer i ørigt, at han har haft vanskeligt ved at indse elementernes positive rolle som billeder på sakramentets åndelige virkelighed.

\section{Billedsynets udtryk i billedsproget}

Også i salmernes billedsprog kommer billedsynet til udtryk. I prædikenerne gennemførtes billedsynet på elementerne som sagt sidst på året 1821; men en undersøgelse af salmeproduktionen fra årene før 1821 godtgør, at Grundtvig på det digteriske område længe før 1821 har kunnet betragte elementerne under billedsynets vinkel. I Grundtvigs frie og selvstændige fordanskning fra 1817 af »Morten Luthers Jule-Psalme» hedder et:

Ja, fryd dig, Mark! siung høit, du Skov!

I Muldet gaaer nu Herrens Plov,

Og Selv Han lægger Sæd i Jord

Til Himmel-Brød paa Alter-Bord!

III 67,21

Dette vers, der ikke kan føres tilbage til forlægget, skildrer i naturbilleder inkarnationen. Ordet bliver kød (sæden lægges i jorden), og det spæde Jesus-barn vokser op til at blive Himmelbrødet. Det naturlige brød, som markerer afslutningen på den vækst- og forædlingsproces, der begyndte med såningen, er et billede på den ved nadveren nærværende Kristus, der giver sig selv hen for nadvergæsterne. Grundtvig har her udnyttet hele det billede på vækst og næring, som almindeligt brød er.

Samme år gendigter Grundtvig et Kingovers således:

Tak for Dug i Daabens Væde!

Tak for Mad paa Naadens Bord!

III 65,9

Forlægget lyder: 
Tak for Daabens hellig Væde,

Tak for Naaden paa Dit Bord,

Grundtvig vælger billedrige ord fra hverdagslivet. Dug og mad er ikke særlige kultiske begreber eller specielle kirkelige ord; men de afbilder på et højere åndeligt plan, hvad de er på det profane, naturlige og almenmenneskelige, nemlig livgivende næring for det levende. Overalt i Sang-Varket gør Grundtvig på lignende måde brug af brødets og vinens naturlige billedkraft.

Dette syn på elementerne bekræfter Grundtvig i prædikenerne. Septuagesimasøndag 1850 siger han således: »ligesom der staaer skrevet at Brødet styrker og Vinen glæder Menneske-Hjertet, saaledes er Brød og Viin som den bedste Mad og Drikke Lignelsen, hvorunder Liv og Aand meddeles paa Jorden“ (s. 8). Elementerne er lignelser af de åndelige ting, som sakramentet meddeler.

En nøjere undersøgelse af salmer og prædikener viser, hvilke billedfunktioner Grundtvig udleder af brødet og vinen. Det forholder sig således, at Grundtvig ikke er bundet af een bestemt symbolik. Tværtimod udnytter han al den billedkraft, som elementerne besidder såvel i religiøs som i profan sprogbrug. Klart er det, at brødet og vinen ikke udelukkende afbilder de antropologiske størrelser kød og blod. Det skal indrømmes, at denne symbolik også er at finde hos Grundtvig; men den dominerer på ingen måde.

Følgende eksempel fra 1843 illustrerer, hvorledes Grundtvig på en for ham karakteristisk måde bruger brødets og vinens billedkraft:

Med Hans Ord vi i vor Daab

Favne Herlighedens Haab,

Smage ved Hans Bord paa Tue

Livets Brød og Gloedens Drue!

Os beredt paa Kongesæde

Evigt Liv og salig Glade!

III $225,3-4$

(mine udhævelser) 
Vægten ligger ikke på brød og vin, men på livet og glæden. Brød er et naturligt billede på liv, og ligeledes er druen (og vinen) glædens symbol. Ganske givet tænkes der med udtrykket "Livets Brød» også på Johs. 6,48; men dær ligger vægten netop også på brødets billedlige betydning som det nødvendige til livets opretholdelse. Grundtvig er langt fra at sige, at brødet er Jesu legeme, og at vinen er Jesu blod.

Brød og vin kan altså i overensstemmelse med almindelig sprogbrug anvendes som billeder på liv og glæde. Men også vinen alene kan fungere som billede på både liv og glæde. I en prædiken til palmesøndag 1846 siger Grundtvig: "...under Striden om Vinens virkelige Deel i Nadverens Velsignelse, har vi næsten aldeles overseet dens Betydning, som det naturlige Billede på Liv og Glade, skiøndt det er klart nok, at kun fordi den er det, har Herren opløftet den i Nadveren ved Siden ad Brødet, det naturlige Fødemiddel« (s. 6). Her går Grundtvig så vidt som til at sige, at elementernes anvendelse ved nadveren er betinget af deres evne til at afbilde evangeliet og frelsen. I samme prædiken siger han i øvrigt, at vinen i nadveren minder os om sammenhængen mellem det synlige og det usynlige, mellem det legemlige og det åndelige og mellem det jordiske og det himmelske (s. 5). Med andre ord: det jordiske afspejler det himmelske. I det synlige findes et sandt billede af det usynlige. Sandt er billedet, fordi det jordiske og synlige er skabt af det himmelske og usynlige. Pointen i denne sammenhæng er, at nadverelementerne ikke danner undtagelse. Også det synlige ved nadveren må tjene som billede.

\section{Alterkalkens og vinens motivkreds}

Grundtvigs billedsprog udmærker sig derved, at billedernes betydning ikke er entydigt fastlagt én gang for alle. Det hænger sammen med, at den direkte tydningspoesi, der betjener sig af faste ordbetydninger og fremstiller en sag uden appel til fantasien, nærmest var en vederstyggelighed for Grundtvig. I stedet betjente Grundtvig sig af tilknytningspoesiens hovedprincip, efter hvilket en sag beskrives gennem dens tilknytninger, afbildninger, attributter, biforestillinger og indirekte betydninger. 
Nærværende afsnit har som sit mål at klarlægge den motivkreds, hvori alterkalken og vinen indgår; og med motivkreds menes relationsmønsteret mellem en given sag (f.eks. et teologisk begreb) og dets forskellige tilknytninger, billeder og biforestillinger.

Vi tager udgangspunkt i Grundtvigs forestilling om, at nadveren har en ekklesiologisk eller menighedsdannende funktion. Dåben er kirkedannende i egentligste forstand; men nadveren er kirkefuldendende. Ved nadveren bliver den endegyldige menighed til. Nadverens kirkefuldendende funktion består deri, at den forener den nadverfejrende menighed til Kristi legeme.

$\mathrm{Nu}$ kunne man med en vis rimelighed forvente, at Grundtvig knyttede til ved 1.Kor.10,17, der taler om det ene brød og det ene legeme, når han gennem billedsproget skulle udtrykke nadverens ekklesiologiske funktion. Men Grundtvig benytter sjældent dette skriftsted. Det ene brød er for Grundtvig i overensstemmelse med Johannesevangeliet Kristus selv. Nadverens menighedsfuldendende funktion udtrykkes altså ikke ved brødets billede. Grundtvig benytter derimod alterkalken og vinen som billeder på denne sag; men for at vise det må vi gå en omvej.

Det, der forener menigheden, er karligheden. »Kiarlighed, oprigtig og uforkrænkelig Kiærlighed er det eneste, som virkelig og varig kan forene Menneske-Hjerter«, siger Grundtvig på skærtorsdag 1853 (VP, s. 319). Og på 2.s.e.trinitatis 1847 opfordrer han til at "komme ihu, hvad det er, som aandelig og levende kan forene Menneskens Børn enten med Gud eller med hinanden, og veed vi nu alle, at det er ingenlunde udvortes og synlig Mad og Drikke, men ene og alene inderlig, uskrømtet Kiærlighed ..." (s. 6).

Netop ved nadveren lyder kærlighedens ord, det kærlighedens ord, som skaber og opholder de helliges samfund og den virkelige forening mellem Kristus og menigheden som hans åndelige legeme:

Kiærlighed os sammensmelte

Til din Ære, paa dit Ord!

Skab med Det et Folk af Helte

Paa vort Knæ-Fald om dit Bord,

$$
\text { III } 114,16
$$

Som sagt udnytter Grundtvig ikke det nytestamentlige forlæg for at 
lade brødet afbilde nadverens menighedssammenføjende funktion. Derimod findes der en række eksempler på, at Grundtvig udleder en ekklesiologisk betydning af det andet element, kalken/vinen.

Den Stad uden Mage,

Af levende Stene,

Som frit sig forene,

Paa hellige Dage,

Opbygges med Kiærligheds Kalk!

Ja, Kiærligheds-Aanden,

Som Alting formaaer,

Det giør efterhaanden,

Som godt Han forstaaer;

Problemet ved denne og lignende tekster er, om udtrykket »Kiærligheds Kalk" refererer til alterkalken eller betyder kærlighedens sammenføjende og forenende væsen og egenskab, således at billedet, som Grundtvig benytter, ikke er alterkalken, men cement og mørtel.

Der findes belæg for, at Grundtvig faktisk udnytter den billedkraft, som ligger i cement og mørtel. Eksempelvis taler han på skærtorsdag 1826 om templet, som er bygget af de kristnes mangfoldighed som levende stene, der opmures i »Kiærligheds Kalk« (s. 7). Et andet eksempel er 6.s.e.trinitatis 1868, hvor det hedder, at "indbyrdes Kjærlighed alene er den aandelige Kalk, hvormed Hjærter kan forbindes til virkeligt og levende Fællesskab« (SP, II, s. $118 f$.$) .$

Jeg tror ikke, det er en fyldestgørende forklaring blot at henvise til de nytestamentlige forlæg for 'mure-billedet', f.eks. 1. Peter 2,5 og Ef. 4,16, der taler om, at legemet opbygges i kærlighed:

Forholdet lader sig bedst forklare som billedmøde eller billedkonvergens, idet billedmøde eller billedkonvergens dækker over det fænomen, at to billeder via fællesskab om eller væsentlig lighed $i$ biforestillinger, associationer og bibetydninger får samme direkte tydning. De to billeder alterkalk og mørtel bliver i kraft af fælles biforestillinger og associationer billede på det samme, nemlig kær- 
ligheden, der alene kan sammenføje hjerter. Udtrykket »Kiærligheds Kalk" rummer altså to billeder.

Dette er dog kun den ene side af fænomenet; for billedmøde indebærer også, at det ene billedes biforestillinger og tilkytninger kan overføres til det andet billede. Alterkalken og mørtel er fælles om en sproglig tilknytning, nemlig ordet kalk. Via dette tilknytningsfællesskab kan andre tilknytninger overføres fra det ene billede til det andet. Alterkalken modtager således "opmure« og »opbygge«, der normalt er biforestillinger til mørtel og cement.

Idet vi ser ser bort fra billedet mørtel, omfatter motivkredsen foreløbig ordene: alterkalk, kærlighed, hjerternes forening; men kredsen er større endnu. Kærlighed er nemlig et andet udtryk for eenhedens Ånd. De følgende verslinier er eksempler på, hvor nært Grundtvig knytter kærligheden og Ånden til hinanden:

\section{Kiærligheds og Sandheds Aand! \\ Jords og Himmels Hjerte-Baand \\ Knytter Du alene;}

$$
\text { I } 348,1
$$

O, Kiærligheds Aand!

Som væver i Sandhed Fuldkommenheds Baand!

$\mathrm{O}$, smelt du vort Hjerte ved Høialtrets Ild,

IV 267,7

Den fælles association for kærligheden og Ånden er evnen til at forene og forbinde menigheden. Kærligheden forbinder hjerter og Ånden forbinder sjæle. Således opbygges menigheden til Kristi legeme: "At det er Hans, Vorherres Jesu Christi Aand og Kiærlighed, som giør det store Underværk at forbinde og forene alle hans Troende til eet Legeme i ham, det følger af sig selv. Thi kun Aanden kan forbinde Sjæle, kun Kirlighed kan forbinde Hjerter, og det er jo Meningen med det ene Legeme i Christo, at vi alle skal være 'eet Hjerte og een Sjæl'..." (VP, s. 92).

Ligesom kærligheden spejler sig i alterkalken, således findes Åndens afbildning også på alterbordet. Vinen er nemlig det stående 
billede på Ånden, siger Grundtvig. Pinsesalmen "Apostlerne sad i Jerusalem « viser dels, at vinen fungerer som billede på Ånden, og dels at Grundtvig tænker nadverfejringen og pinsebegivenheden nært sammen. Han lader nemlig Gud sige til Kristus:

Den Aand, som nu kun er min og din,
Vi maae da med Smaafolk dele,
Og skiænke dem lidt af den søde Vin,
Som fryder os i det Hele!

II 92,7

De to første linier siger det samme som de to sidste (leddenes parallelisme). Ånden og vinen betegner derfor samme virkelighed. At nadveren også er tænkt med i denne pinsesalme, fremgår af det 3. vers, der lyder:

Der taldes om dem, som Livets Ord

$\mathrm{Nu}$ skulde med Kraft forkynde,

Om Himmel-Glæden ved Herrens Bord,

Som skulde paa Jord begynde.

Sakramenternes kraft kunne først vise sig efter Helligåndens udgydelse; for apostlene fik de glødende tunger på pinsedagen for at tale det levende Ord ved dåben og nadveren.

Den ene Ånd, som vinen afbilder, beskriver samme virkelighed som det ene legeme. Men enhedens Ånd er også uadskillelig fra pinsebegivenheden. Og videre kaldes pinsen "Kiærlighedens Fest" hos Grundtvig. Ligheden mellem betegnelserne "Kiærlighedens Fest« og »Kiærlighedens Maaltid « (nadveren) er ingenlunde tilfældig. Grundtanken er den, at pinseunderet bliver nutid i og med det levende Ord, som Helligånden taler ved nadveren.

Pinse og nadver forbindes indbyrdes på en sådan måde, at de gensidigt afbilder hinanden. Pinsen kan være et billede på nadveren og omvendt.

Motivkredsen, som vi har søgt at klarlægge, kan opstilles som nedenfor, idet man må tænke sig til forbindelseslinier mellem de enkelte motiver. 
Alterkalken Vinen

Nadver

Pinse

Kærligheden

Ånden

Eet hjerte

Een sjæl

De troendes forening

til det ene legeme

\section{Billedsynet og Irenæuspåvirkningen}

Origenes’ og Grundtvigs syn på nadverelementerne minder meget om hinanden. Begge benægter, at sakramentets virkning er knyttet til brødet og vinen. Ordet tillægges af begge den altafgørende betydning. At spise Kristi legeme og drikke hans blod er at tilegne sig hans ord. For Origenes er elementerne symboler og for Grundtvig er de billeder. Det spørgsmål, som herefter må besvares, er, om Grundtvig modsigelsesfrit fastholdt dette syn på elementerne, efter at han var kommet under indflydelse af Irenæus, hvis elementsyn var diametralt modsat Origenes'. Spørgsmålet er reelt, fordi der hos Grundtvig findes eksempler på talemåder, der tydeligvis er inspirerede af Irenæus, og som kan tolkes helt bastant sakramentalistisk.

Er der alligevel en uklarhed om elementernes status i Grundtvigs nadverteologi? På den ene side findes det klart formulerede billedsyn: elementerne afbilder Ordets virkning. På den anden side befinder sig de udsagn, som synes at forudsætte, at elementerne er andet og mere end naturligt brød og vin, og som tilsyneladende knytter sakramentets ydre side sammen med en legemlig virkning, som rækker ud over døden.

Det forholder sig ikke således, at den sidste gruppe udsagn tager til i antal hos den ældre Grundtvig. Sidste Praedikener indeholder ganske vist også sådanne eksempler; men denne prædikensamling er i virkeligheden et tydeligt bevis på, at også den ældre Grundtvig fastholdt forestillingen om Ordets altafgørende primat ved nadve- 
ren. Tanken om Ordet som eneste kraftbærer fastholdt Grundtvig hele livet.

Hvis der er tale om en sakramentalistisk tendens hos Grundtvig, må forklaringen altså søges i en tidligere periode af hans liv. Da anliggendet $i$ de problematiske udsagn i regelen er at pointere den legemlige virkning af nadveren, er det naturligt at foretage en undersøgelse af Grundtvigs begrundelse for denne virkning.

Spørgsmålet er altså, om Grundtvig mener, at den ydre side af sakramentet er årsag til en ydre virkning på nadvergæsten. Har nadverbrødet og nadvervinen en indvirkning på legemet, som rækker ud over døden? En ændring i elementsynet bort fra den billedlige betragtningsmåde i retning af Irenæus' sakramentalistisk klingende opfattelse må vise sig i begrundelsen for den legemlige virkning af nadveren. Undersøgelsen af synet på den legemlige virkning kan vise, hvor dyb overensstemmelsen med Origenes i virkeligheden er, og i hvor høj grad den irenæiske teologi har vundet indpas $\mathrm{i}$ Grundtvigs tænkning. Origenes regnede jo i modsætning til Irenæus ikke med en legemlig virkning af nadveren.

Grundtvigs mening om den legemlige virkning af nadveren er uafklaret $\mathrm{i}$ begyndelsen af tyverne. Når han enkelte gange i forbindelse med nadveren nævner en legemlig virkning, er der snarere tale om det almindelige kristne opstandelseshåb end om en speciel virkning af dette sakramentes ydre side. Om og i givet fald hvornår Grundtvig tilegner sig tanken om en speciel legemlig virkning af sakramentets ydre side, er vanskeligt at afgøre. Vi må nøjes med at konstatere, at fra 1832 findes eksempler, der kan tolkes i den retning. Som eksempel kan nævnes I 96,3:

Ja, vor Drot, som Skaber-Ordet,
Selv velsigner Brød og Viin,
Herrens Røst er Sjæle-Bordet,
Selv for Engle Spise fiin,
Ordet dog, som os har vundet,
Til vort Legems Tarv forbundet
Har sin Kraft med Brød og Viin!

Baggrunden for formuleringer af denne type er sandsynligvis at finde $i$ en voksende sympati for den irenæiske teologi med dens positive forhold til legemligheden. 
Vigtigere end at fastlægge tilegnelsestidspunktet er det at spørge efter den teologiske begrundelse, Grundtvig fremfører for en forbindelse mellem nadveren og kødets opstandelse. De af Grundtvig anførte grunde kan groft taget opdeles i to kategorier. Den ene består af de udsagn, hvor Ordet angives som årsag, og hvor sakramentets ydre side ingen rolle spiller: "og veed vi nu, at hans [Haands-]Paalæggelse i Ordet ved Daaben frugtede til Liv af Døde for vor Sjæl, hvor skulde vi da tvivle om den samme Frugt af Ordet ved Nadveren: det er mit Legeme« (PF, s. 369). Sakramentordet giver nadvergæsten delagtighed i Kristi opstandelseslegeme, "saa naar vi tage ham paa Ordet, da har vi ham vist, og blive, som Apostelen siger om Kristus og Menigheden, af hans Kjød og Ben, faa Del i ham baade med Sjæl og Legeme, saa vor Sjæl lever op i hans Aand og fryder sig i sin Gud og Frelser, og Legemet indvies til Uforkrænkelighed, til en ærefuld Opstandelse ligesom hans" (PF, s. 284). Den her anførte begrundelse for nadverens legemlige virkning er helt i overensstemmelse med og en logisk konsekvens af 1.Kor.10,16, hvis ord Grundtvig så ofte gjorde til sine egne. Ved hjælp af dette skriftsted forstår han nadveren som et skæbnefællesskabsmåltid, hvor nadvergæsten indlemmes i Kristi legeme og dermed får lod og del fælles med den opstandne. Ikke elementerne, men Ordet, Velsignelsen, virker den fuldstændige forening med Herren. Heraf følger som en nødvendighed den legemlige opstandelse. Tanken om en legemlig virkning er logisk indarbejdet under grundforestillingerne om Ordets primat og om nadverens ekklesiologiske funktion.

Den anden kategori består af de udsagn, som synes at tillægge de legemlige nadverelementer en vis andel i den legemlige virkning på nadvergæsten:

Hvede-Kornet og Vin-Ranken

Selv sig kalder Herre min, Saa med Flid Han fører Tanken

Hen til Bordets Brød og Viin,

Hvor det Himmelske i Aanden,

Og det Jordiske i Haanden,

Sammensmelte, Eet i Grunden,

Som i Ordet, saa i Munden,

Til vor Sjaels og Legems Tarv! 
Her synes elementerne at være andet og mere end naturligt brød og vin. Det jordiske og håndgribelige og det himmelske og åndelige smelter å benbart sammen både i Ordet og i elementerne. Hvorledes kan Grundtvig sige dette 'både - og' uden at modsige sig selv? Verset er tydeligvis inspireret af Irenæus, der som nævnt hævdede, at det brød, hvorover indstiftelsesordene har lydt, ikke mere er almindeligt brød, men sammensat af en himmelsk og en jordisk bestanddel. Spørgsmålet er, om Grundtvig her viger fra sin grundopfattelse, at indtil Gudsrigets synlige åbenbarelse smelter det legemlige og det åndelige kun sammen i det hørlige Ord.

Et andet eksempel under samme kategori er prædikenen på septuagesimasøndag 1834 (PF, s. 222ff.). På baggrund af denne prædiken siger Kaj Thaning (Menneske forst -. s. 549), at Grundtvig her i 1834 kan tolke Irenæus uden som tidligere at indblande romantikkens syn på det sanselige og skabte som noget lavere og syndigt. Thaning har ganske givet ret i, at Grundtvig er inspireret af Irenæus i denne prædiken. Den stærke betoning i forbindelse med nadveren af legemets opstandelse under henvisning til, at frelseren vil udløse hele skabningen, sådan som den er skabt, med sjæl og legeme, minder meget om Irenæus. Ligeledes støttes Thanings tolkning af det skabelsesteologiske syn, som prædikanten anlægger på elementerne. Grundtvig taler (ligesom Irenæus) om, at Herren i nadveren tilegnede sig den første skabning, da han indoptog elementerne i sit legeme og blod ved at omtale dem i indstiftelsesordene. Ligesom $\mathrm{i}$ det foregående eksempel kan ånd og legeme tilsyneladende forbindes i nadveren. Brødet og vinen hæves op fra symbolernes skyggeverden og nærmer sig virkelighedens verden, hvor man spørger efter virkning og ikke efter betydning. Det ser ud til, at brød og vin på det legemlige plan har en virkning på legemet, medens Ordet på det åndelige plan har en virkning på sjælen.

Er dette foreneligt med, hvad Grundtvig ellers siger om Ordets primat? Kan man i det ene øjeblik begrunde den legemlige virkning med en åndelig delagtighed i Herrens kød og blod, dvs. et skæbnefællesskab om Kristi opstandelseslegeme, og i det næste øjeblik henføre den til de indviede elementer uden at modsige sig selv?

Det er klart, at når det åndelige, dvs. Ordet, foruden en indvirkning på sjælen også har en evig virkning på legemet, således som det naturlige, dvs. brødet og vinen, har en øjeblikkelig virkning, så er det kun et lille spring at lade de af Ordet velsignede elementer 
fremtræde som forudsætningen for den evige virkning. Det afbildende og det afbildede smelter let sammen. Men spørgsmålet er, om der blot er tale om en sådan sammensmeltning, eller om elementerne virkelig har ændret status.

Septuagesimaprædikenen er et interessant eksempel, fordi billedsynet her findes side om side med et irenæisk syn på nadverelementerne. Ved nadveren »er Brødet og Vinen ikke blot Billeder «(s. 223), siger Grundtvig; men billeder er de altså også! Overensstemmelsen med Irenæus' nadverlære er måske ikke så fuldstændig endda. Grundtvig siger ikke, at elementerne er Kristi legeme og blod, således som Irenæus gør. Derimod siger han, at »ligesom han virkelig forvandlede Vand til Vin ved Brylluppet i Kana i Galilæa, saaledes har han jo virkelig helliget og velsignet Vinen med Brødet paa sit Bord, saa Velsignelsens Kalk, som vi velsigne, er Kristi Blods Samfund" (sst.). Vinen forvandles ikke, som man skulle vente efter sammenligningen med underet i Kana; men den velsignes og helliges, så nadvergæsten får delagtighed $\mathrm{i}$ Kristi blod i og med delagtigheden i kalken. Grundtvig betjener sig her af den paulinske sprogbrug i 1.Kor.10,16, som for ham var et værn mod dogmet om en udvortes nærværelse.

Det kan heller ikke udlægges som en identificering af brødet og vinen med legemet og blodet, når Grundtvig siger, at vinen »er af Herren selv i sin jordiske Skikkelse sat ved Siden af Brødet paa hans Bord, til at sammenflyde med hans Blod i Velsignelsens Kalk, som er Udødeligheds-Bægeret for os baade til Sjæl og Legeme« (s. 225). Dette udsagn må forstås således, at hvor der er delagtighed i vin i dens jordiske skikkelse ved nadveren, dær er der også delagtighed i Herrens Blod. »Velsignelsens Kalk« og»Udødeligheds-Bægeret « betyder den kalk, som ledsager det levendegørende Ord. Vinen forbliver vin; men det er rigtigt, at elementerne er hævet op fra en skyggetilværelse. Det legemlige er blevet virkeligt; det har Grundtvig lært af Irenæus. Men det legemlige er ikke dermed blevet åndeligt og bliver det heller ikke før på den yderste dag, selv om Ånden forbinder sig med det her og nu.

At det legemlige tilkendes realitet, er derfor ikke ensbetydende med, at billedsynet opgives. Septuagesimaprædikenen kan læses som et forsøg på at kombinere romantikkens billedsyn med Irenæus' positive forhold til det legemlige. Det legemlige er blevet virkeligt, hvorfor også nadvervinen er blevet virkelig, almindelig vin, der 
såvel ved nadverbordet som ved ethvert andet bord nærer legemet $\mathrm{i}$ overensstemmelse med skabelsens orden; men dette udelukker ikke elementernes billedkraft. Grundtvig siger da også i prædikenens indledning om Ps. 104,15, at Ånden forstår at vælge sig billeder på sig og sin guddommelige virksomhed, hvor de virkelig findes; og Åndens billede findes netop på nadverbordet i vinen.

\section{Det afbildende og det afbildedes sammensmeltning}

De ovenanførte teksteksempler viser, at Grundtvig tilsyneladende fremfører to forskellige begrundelser for nadverens legemlige virkning. I de første eksempler var Ordet enevirkende årsag, medens sakramentets ydre side syntes at spille en rolle i de sidste teksteksempler. Vi spørger igen, om Grundtvig modsiger sig selv. Står han splittet mellem en billedlig og en realistisk tolkning af ordene: det er mit legeme/blod? At der ikke er tale om to skarpt afgrænsede grupper af hinanden modsigende udsagn, viste det sidste eksempel (septuagesima 1834). Både den realistiske og den billed lige tolkning findes åbenbart inden for en og samme tekst. Det er svært at forestille sig, at Grundtvig har set nogen modsigelse, når han i den samme prædiken kan anlægge begge synspunkter. Jeg finder ikke tilstrækkelig forklaring i den tese, at Grundtvig er blevet fascineret af tanken hos Ireænus om skabelsens genoprettelse, men blot ikke har formået at integrere den modsigelsesfrit i sit eget nadversyn. Eller sagt på en anden måde: hos Irenæus har Grundtvig mødt det forløsende, positive syn på legemligheden; men lige præcist på det nadverteologiske område kniber det med en helhjertet tilslutning, fordi han ikke vil opgive billedsynets måde at betragte nadverelementerne på. Når denne tese ikke er tilfredsstillende, må vi altså søge en anden forklaring, som tillader billedlige og realistiske udsagn side om side.

Elementerne ændrer ikke status; men de bliver som alt andet, der er skabt, virkelige og reale. Kombineret med et konsekvent billedsyn og med tanken om, at frelse er skabelsens genoprettelse, betyder det, at det afbildende og det afbildede smelter sammen; og dette er vel at mærke ikke en lapsus, men tværtimod det tilsigtede mål. "Pædagogisk « er det en betænkelig kombination, fordi resultatet i 
læserens øjne kan tage sig ud som en modsigelse. Årsagen til kombinationen af billedsyn og skabelsesteologi er den lige vægtige interesse både for det afbildende og det afbildede, både for det jordiske og det himmelske. Hverken det afbildende eller det afbildede er målet for Grundtvig, men kun en trosrelevant enhed mellem begge (se hertil Helge Toldberg: Grundtvigs symbolverden, side 216). For troens øjne ophøjes spejlingen til billedlig realitet. Dette gælder ritualordet, der er, hvad det betyder; men det gælder også elementerne. Brødet er blevet virkeligt, og i troens øjne er det da, hvad det betyder; men skellet mellem synligt og usynligt ved nadveren er ikke ophævet; det sker først ved den sidste store nadver. Først da skal brødet og vinen virkelig vare (dvs. virke), hvad de nu betyder. Det afbildende og det afbildede smelter sammen $i$ det åndeliges, men ikke $i$ det håndgribeliges sfare. Kun for troens øjne bliver den kommende sammensmeltning mellem synligt og usynligt nutid ved nadveren. Når Grundtvig kan sige:

\author{
Hvede-Kornet og Vin-Ranken \\ Selv sig kalder Herre min, \\ Saa med Flid Han fører Tanken \\ Hen til Bordets Brød og Viin, \\ Hvor det Himmelske i Aanden, \\ Og det Jordiske i Haanden, \\ Sammensmelte, Eet i Grunden, \\ Som i Ordet, saa i Munden, \\ Til vor Sjaels og Legems Tarv!
}

I 145,2

så er der tale om forkyndelse, der kun har relevans i den åndelige sfære, hvori troen lever. Det fremgår af salmens første vers, der i modsætning til vers 2 ikke kan siges at være inspireret af Irenæus. I vers 1 siger Grundtvig, at jord og himmel sammensmelter »under Ordets Telte«, hvilket må være en hentydning til indstiftelsesordenes udsagn om brødet og vinen: det er mit legeme/blod. I indstiftelsesordene er brødet og vinen optaget (PF, s. 225). Jord og himmel smelter ikke sammen i brødet og vinen, men derimod i Ordet, der taler om brødet og vinen, og i munden, der både kan kalde Herren for hvedekornet, livets brød, vinranken osv. og smage disse billedrige, skabte ting: brød og vin. 
Elementerne forvandles ikke substantielt til et lægemiddel til udødelighed. Indviet brød og vin er under en substantiel synsvinkel identisk med alt andet brød og vin; men i Helligåndens sfære sker der på baggrund af den i skabelsens orden indbyggede spejling en trosrelevant identifikation, således at elementerne fremtræder som årsag til den legemlige virkning af nadveren. Brødet og vinen er sikre tegn og panter på denne virkning.

Ud fra den her forsøgte opklaring af den tilsyneladende modsigelse i Grundtvigs nadversyn bliver følgende tekst forståelig, og omvendt er denne tekst et argument for forklaringen. Grundtvig siger 7.s.e. trinitatis 1841: $O \mathrm{Og}$ see $\mathrm{m}$ [ine] V[enner] for at Ligheden kunde være fuldstændig, for at Dagens Evangelium ret kan være os et Speil paa vor usynlige, men dog altid nærværende, kiærlig og almægtig virksomme Herre og Mester, saa er jo Bespisningen ved Hans Bord jo i Aandens Verden netop det Samme som Miraklet med de Firetusinde i Haandens Kreds. Han ynkes hjertelig ogsaa over vort Støv, Han veed, det maatte forsmægte paa den lange Reise til vort rette Hjem, de evige Boliger, derfor vil Han ogsaa legemlig bespise os med Mad som kan vare til et evigt Liv, saa vort Kiød og vort Hjerte skal ikke anderledes forsmægte, end at de reise sig igien og mættes for Guds Ansigt i Herlighed, og derfor tager han en Smule Brød og en Taar Vin af vor Haand, takker og velsigner og giver os det igien at række til Folket paa Jorden ... og da mættes Millionerne" (s. 6).

Man kunne fristes til at tro, at Grundtvig her helt overgiver sig til den irenæiske teologi: den legemlige side af nadveren har en legemlig virkning. Men man skal bemærke, at nadveren hører hjemme i Åndens og ikke i håndens verden. Bespisningen (og i det hele taget ethvert måltid) er nadverens afbildning $\mathrm{i}$ det håndgribeliges verden. Når der tales om en legemlig bespisning ved nadveren, er den altså at forstå som en åndelig legemlighed. Det forudsatte billedsyn giver frihed til at forkynde i meget realistiske billeder. For troen, dvs. i Ånden, er brødet, hvad det betyder. Den højere enhed mellem det afbildende og det afbildede, mellem timeligt og evigt og mellem det skabte og Skaberen har Grundtvigs interesse ("for at Ligheden kunde være fuldstændig «). Den endegyldige overskridelse af skellet mellem Ånd og legeme, som nu sker fuldstændigt (dvs. også sanseligt) i det hørlige ord, den skal engang også omfatte det synlige ved nadveren. Også det synlige skal engang blive et fuldkomment red- 
skab for Ånden; men for troens øjne er spejlingen allerede nu ophøjet til realitet. Spørges der om den strikte teologiske begrundelse for den legemlige virkning, så skal Grundtvig nok vide at pege på velsignelsen og på Ordet. Det er velsignelsen, som mætter, siger han flere gange i denne prædiken (7.s.e.trinitatis 1841).

Forholdene omkring den legemlige virkning af nadveren oplyses af den iagttagelse, at Grundtvig også kunne tale om en legemlig virkning her og $n u$, en virkning, som på ingen måde kan opfattes groft og bastant. Gennem de få tekster, hvor Grundtvig nøjere beskriver denne legemlige virkning her og nu, får man et godt indtryk af, hvorledes Grundtvig forestillede sig den legemlige opstandelse som en åndeliggørelse af legemet. Opstandelsen sker ikke uforberedt, men er derimod fuldendelsen af kristenmenneskets vækst i Helligånden.

Den legemlige virkning her og nu berører hjertet, tungen og forstanden. Disse tre menneskelige organer er hver for sig sider af menneskets væsen, som vidner om en åndelig legemlighed, og som gør det muligt at forestille sig en åndeliggørelse af legemet. Hjertet, tungen og forstanden er ikke bare kødklumper, men redskaber for Ånden og Ordet. Når Kristus kommer synligt igen, skal hele legemet blive et redskab for Ånden, således som hjertet, tungen og forstanden kan være det allerede nu.

\section{Skabelsesteologi på billedsynets præmisser}

Hos Irenæus mødte Grundtvig et nyt syn på legemligheden. Tanken om, at også det legemlige var omfattet af frelseshistorien, forløste hos Grundtvig en revaluering af det synlige. Dette er dogikke således at forstå, at skellet mellem synligt og usynligt dermed faldt bort. Denne sondring samt forestillingen om det åndeliges spejling $i$ det legemlige berørtes ikke af Irenæuslæsningen: "Han som skabde det Udvortes, er det ikke den Samme, som skabde det Indvortes, og hvad skulde vel det Synlige være for Ham, uden Billeder og Tegn paa det Usynlige, eller hvorledes skulde Skabningen aabenbare Skaberen og Gierningen prise sin Mester, naar der var et svælgende Dyb mellem Aand og Legeme og mellem Gud og Menneske» (SB, II, s. 373).

For en skabelsesteologisk vurdering er der ikke et "svælgende" dyb mellem Ånd og legeme; men et skel består dog fortsat for Grundtvig. Broen over dette skel udgøres af spejlingen, der er indbygget i skabelsens orden. Det skabtes billedkraft har sin yderste grund i, at det udvortes og det indvortes har samme Skaber. Grundtvig tager altså skabelsesteologien til indtægt for billedsynet. 
Han integrerer på billedsynets præmisser det positive syn på legemligheden i sin egen verdensforståelse. Man må sige både Ånd $o g$ legeme for at omfatte hele virkeligheden; men først på den yderste dag skal det legemlige og det åndelige forenes, "saa de skal hverken skilles ad eller regnes hver for sig“ (VP, side 118). Indtil da kan Ånden forbinde sig med det legemlige; men dette sidste bliver ikke af den grund åndeligt. Ånden kan således forbinde sig eller sammensmelte med brødet og vinen $i$ Ordet, som omtaler disse elementer, men ikke i elementerne selv.

Herrens Ord, og intet andet, Troens er og Livets Grund, Brød og Viin og Vievandet, Sammensmeltet i hans Mund Med Livs-Ordet, dog hos os Ormegaarden bydes Trods!

I indstiftelsesordene smelter brødet og vinen sammen med Livets Ord; men fordi elementerne ikke er åndelige, kan de ikke virke opstandelsen, der består $\mathrm{i}$, at legemet bliver åndeligt. Kun noget åndeligt kan have en sådan virkning. Sammensmeltningen mellem Ånden og elementerne, som den fremtræder inden for billedsprogets rammer, er forkyndt endetidsbegivenhed: først ved den sidste store nadver skal skellet mellem synligt og usynligt ophæves. Kun i ritualordene sker en sanselig, fuldstændig sammensmeltning her og nu af Ånd og legeme. Ritualordene er åndelige i modsætning til elementerne, der først engang skal blive det.

Irenæus' fortrin i Grundtvigs øjne er, at han forfægter legemets opstandelse "uden dog noget Øieblik at forvexle denne Verden med den Tilkommende, eller at støde an mod den Christelige GrundSætning, at Legemet maa i Sandhed blive aandeligt, før det GudsRige kan udvortes aabenbare sig, som nu kun er inden i os" $(\mathrm{Om}$ Kiødets Opstandelse og det evige Liv af Biskop Irenceus, fordansket ved Nik. Fred. Sev. Grundtvig, K bh. 1855, side 8). Også nadverelementerne hører med til denne verden og ikke til den tilkommende. Elementerne er en del af det skabte; og dermed er de virkelige; men de er ikke åndelige.

Grundtvig har tilsluttet sig Irenæus for så vidt angår den legemli- 
ge virkning af nadveren, og dermed har han distanceret sig fra Origenes; men elementerne tolkes fortsat billedligt i modsæt ning til Irenæus. Grundtvig har ikke overtaget Irenæus' nadverteologi; han har tolket og udnyttet den. Den irenæiske skabelsesteologi fik den indflydelse på Grundtvigs nadveropfattelse, at Origenes'skabelsesfjendtlige symbolske elementtolkning blev undveget til fordel for den originale billedlige tolkning.

Følgende note i Grundtvigs oversættelse af Irenæus viser, hvorledes han har tolket denne oldkirkelige teolog: "Irenæi TankeGang: at det ligesaavel i Nadveren, som i Daaben, er Guds Ord, der skaber og gavner, som Liv og Aand, kan umuelig falde Lutheranere fremmed « (s. 14). Grundtvig har ment, at også hos Irenæus ligger hele vægten på Ordet i 'grundtvigsk' forstand, og der findes da også udsagn, som gør en sådan tolkning nærliggende. Irenæus siger ifølge Grundtvigs oversættelse dels, at årsagen til den legemlige opstandelse er »Guds-Ordet«, dels at Kristi hele menneskelighed er "virkelig tilstede i Guds-Ordet" (s. 14). Men med til billedet af Irenæus' nadverlære hører også den realistisk klingende tale om elementerne som Kristi legeme og blod. Hvad stiller Grundtvig op med disse udsagn, som andre fortolkere har lagt hovedvægten på? Svaret er måske, at Grundtvig i disse udtryksmåder har set en billedlig fremstilling og et produkt af en sammensmeltning af det afbildende og det afbildede. På billedsynets præmisser bliver Irenæus' realistisk klingende talemåder udtryk for spejlbilledets ophøjelse til trosrelevant identitet med det spejlede. Når Grundtvig selv talte tilsyneladende realistisk om elementerne, var det altid på baggrund af billedsynet. Irenæus' forfatterskab er ikke det eneste, i hvilket Grundtvig har indlæst sine egne synspunkter.

\section{Sammenfatning}

Grundforestillingen om, at Skaberen, Frelseren og Helligånden er og virker i Ordet, som bliver hørligt på en mennesketunge, bærer helt og holdent Grundtvigs sakramentbegreb. Nadverordet virker, hvad det nævner, for den, som modtager elementerne. Nadverens frugt er en fuldstændig forening med den Opstandne, hvilket indebærer en opstandelse til en åndelig legemlighed $\mathrm{i}$ lighed med Kristi opstandelseslegeme. 
Til at udtrykke de mange forskellige facetter af nadversynet gør Grundtvig flittigt brug af elementernes naturlige billedevne. Forestillingen om det eviges og det himmelskes afbildning i det synlige og timelige kvalificeres af den frelseshistoriske lære om en enhed mellem Ånd og legeme hos skabningen for syndefaldet og efter Gudsrigets endelige frembrud. Interessen for denne endegyldige enhed fører til trosudsagn, der ophøjer spejlingen til billedlig realitet, og som lader det afbildende og det afbildede smelte sammen. Således kan Grundtvig på billedsynets præmisser lade elementerne fremstå som årsagen til den legemlige virkning.

Når Kristus kommer igen og genopretter alle ting, da skal Ånd og legeme smelte sammen i de synlige ting til en åndelig legemlighed; men indtil da smelter Ånd og legeme kun sammen i Ordet, der kan høres, og som på billedsprogets præmisser kan sige »er « om de synlige ting (Dette er mit legeme/blod); men for troens øjne er sammensmeltningen mellem synligt og usynligt allerede nu en realitet ved nadverbordet (troen foregriber den sidste store nadver), og til at udtrykke dette forhold betjener denne trosforestilling sig af en poetisk identifikation: elementerne bliver ét med den legemlige virknings årsag, men kun under forudsætning af det med frelseshistorien forbundne billedsyn. 